\title{
Should Support Group Intervention be Implemented for Individuals with Stoma?
}

\section{Stomalı Bireylerde Destek Grup Girişimi Yapılmalı mı?}

\author{
(1) Serap Sayar1, (1) Fatma Vural2 \\ 1Dokuz Eylül University Institute of Health Science, Department of Surgical Diseases Nursing, İzmir, Turkey \\ ${ }^{2}$ Dokuz Eylül University Faculty of Nursing, Department of Surgical Diseases Nursing, İzmir, Turkey
}

\begin{abstract}
\|II\|\|\||| ABSTRACT
The presence of stoma in individuals causes physical, psychological and social problems. For this reason, individuals with stoma need effective psychosocial interventions in order to adapt to the stoma. One of these effective psychosocial interventions is support groups. Support groups are defined as groups of individuals with the same problem that provide common support through interpersonal relationships. Individuals generally need to join these groups when natural social support networks are inadequate or if their psychosocial needs are not met. Sharing experiences with other group members in the support group intervention creates positive effects, and solutions are developed for problems with participation in the group. In many studies carried out with other patient groups, support group intervention has positive effects and individuals improve their quality of life. In our country, there is no ongoing support group intervention for individuals with stoma, but in order to help develop psychosocial adaptation to stoma and its effects, nurses should raise awareness about the need for support group intervention and implement these interventions.
\end{abstract}

Keywords: Stoma, support groups, nursing

\section{IIIIIIIII ÖZ}

Bireylerde stomaların varlığı fiziksel, psikolojik ve sosyal yönden sorunlara neden olmaktadır. Bu nedenle stomalı bireyler stomaya uyum sağlayabilmek için etkili psikososyal girişimlere gereksinim duyarlar. Bu etkili psikososyal girişimlerden birisi de destek gruplarıdır. Destek gruplar, kişiler arası ilişkiler yolu ile ortak destek sağlayan, aynı soruna sahip bireylerin oluşturduğu gruplar olarak tanımlanmaktadırlar. Bireyler genelde, doğal sosyal destek ağları yetersiz olduğunda ya da psikososyal gereksinimleri karşılanamadığında bu gruplara katılmaya ihtiyaç duyarlar. Destek grup girişiminde diğer grup üyeleri ile deneyimlerin paylaşılması olumlu etkiler yaratmakta, gruba katılım ile yaşanan sorunlara yönelik çözüm yolları geliştirilmektedir. Diğer hasta gruplarıyla yapılan pek çok çalışmada destek grup girişimin olumlu etkileri olduğu, bireylerin yaşam kalitesini yükselttiği bildirilmektedir. Ülkemizde stomalı bireylere yönelik devam eden bir destek grup girişimi bulunmamaktadır, ancak stomalı bireyler için stoma ve etkilerine yönelik psikososyal uyumun gelişmesine yardım edebilmek için hemşireler destek grup girişiminin gerekliliği konusunda farkındalık yaratmalı ve bu girişimleri uygulamalıdır.

Anahtar Kelimeler: Stoma, destek grupları, hemşirelik

\section{Introduction}

According to Globocan 2012 data published by International Cancer Agency; colorectal cancer (CRC) is the second most common type of cancer in men in the world and the third most common form of cancer in women. According to the 2014 data of the Ministry of Health, CRCs are third in both women and men in our country. The prevalence is 22.8 per hundred thousand in men and 13.8 per hundred thousand in women. ${ }^{1}$ In the treatment of CRC, surgical treatment, chemotherapy or radiotherapy, alternatively adjuvant therapy can be applied, and most of the patients are exposed to stoma during surgery. ${ }^{2}$ Although stoma opening is a surgical procedure commonly used in the treatment of CRC, it is also used in the surgical treatment of inflammatory bowel diseases and traumas. ${ }^{3}$

Presented in: This study was presented by verbal announcement in $16^{\text {th }}$ National Colon and Rectal Surgery Congress (17-30 May 2017, Antalya).

Address for Correspondence/Yazışma Adresi: Serap Sayar MSc,

Dokuz Eylül University Institute of Health Science, Department of Nursing, İzmir, Turkey

Phone: +90 5059102994 E-mail: oranserap@gmail.com ORCID ID: orcid.org/0000-0003-4195-0320

Received/Gelis Tarihi: 25.12.2018 Accepted/Kabul Tarihi: 12.01.2019

${ }^{\circ}$ Copyright 2019 by Turkish Society of Colon and Rectal Surgery

Turkish Journal of Colorectal Disease published by Galenos Publishing House. 
Although stoma indications vary, stoma opening causes lifestyle changes due to loss of fecal control and dependence on bag, causing individuals to experience various physiological, social and psychological problems and adversely affect quality of life. ${ }^{4,5,6}$ Anxiety, change of body image, self-esteem and loss of self-esteem, loss of attractiveness, deterioration of sexual function, fecal leakage, fear of sound/smell and depression are frequently seen problems. ${ }^{5,7,8}$ Because of these problems, individuals tend to restrict themselves and abolish themselves from society. Family relations, work experiences, social and sexual life of individuals are affected negatively. They think that their family and their immediate surroundings are distancing themselves and restrict their interpersonal relations. In individuals, job drop and job efficiency after stoma opening is frequently observed. ${ }^{4,5,6}$ Individuals with stomata are ashamed of thinking that they are disturbing others in social environments with uncontrolled defecations. Accordingly, they isolate themselves from the society and are introverted. ${ }^{9,10}$ Studies have shown that the loss of control over gas and fecal output after stoma opening causes psychological and social isolation in individuals, and that stoma creates negative emotions affecting individuals, interpersonal relationships and body image. It is reported that it cannot carry out leisure activities such as sports and it affects the quality of life negatively. ${ }^{11,12}$

Since most individuals with stomata also fight with cancer, only medical treatment protocols such as chemotherapy, radiotherapy and surgical treatment are not sufficient on the way to recovery. The main treatment criteria are to ensure and maintain the psycho-social comfort of the individual during and after the treatment and recovery period. One of the most important means of providing this is social support. The scope of social support usually consists of family members, close relatives, friends and health care teams (physicians, nurses, social workers, psychologists, etc). Support groups are one of the most important tools that meet social support needs. ${ }^{13}$ These groups play an important role on the social cohesion of individuals. ${ }^{7}$ Social cohesion is that individuals learn to abide by the rules of the society they live in, and develop a behavior that is appropriate to these rules and value judgments. The stages of acquiring the values, behaviors and knowledge of the society in which individuals belong are the process of socialization. This socialization process can affect the family, heredity, whether the individual's health status affects the activities of daily living and affect the peer group. ${ }^{14}$ Nursing interventions aimed at restoring the social cohesion of individuals; psychological support, psychotherapy, social support, inclusion of individuals in other stoma individuals and activating individuals. ${ }^{15}$ Creating support groups by bringing people with stoma together with other people with stoma, sharing feelings, thoughts and problems in these groups, realizing that individuals are not alone, sharing solution suggestions for problems and increasing social support facilitate the social cohesion of individuals. ${ }^{14}$ In this review, it is aimed to emphasize the effects of support group initiatives, one of the counseling roles of nurses, on stoma individuals.

\section{Support Group Intervention}

\section{Definition, Purpose and Importance of Support Group Intervention}

Support group initiative; is a planned and systematic aid process designed for individuals with similar problems or needs by a professional consultant to adapt to daily life and to deal with the problems they face. ${ }^{14}$ Support groups are the groups that provide individuals to share their knowledge, experience and problems in a safe environment and provide support from people with similar diseases. ${ }^{16,17}$ Support groups have five general objectives defined; the support group should empower individuals to cope with their coping skills, provide common points to talk, and share experience and situation sharing, to help the group members to overcome the current problem, to explore knowledge sharing, problem solving strategies, and to evaluate the advantages and disadvantages of various coping methods. The two aims of the support group are particularly important for stoma individuals; information sharing and encouraging individuals. Information sharing is very important because there are various and different skills that enable the successful management of the newly opened stoma within the group. It provides a rich resource for learning the experiences, ideas and attitudes of other individuals in the group. ${ }^{18}$ Support groups allow individuals to realize that they are not alone, to overcome illness and to confront, to provide stress relief to individuals. It gives basic knowledge and skills for social cohesion. With experience sharing, individuals share their feelings and thoughts, and suggestions for problem solving. Support groups provide individuals with the opportunity to assess their own behavior and the problems of others and to develop solutions for solutions, with the support of others, to participate in plans that lead to cognitive and behavioral change. Each member of the group forms a model for learning the appropriate behavior, and the individual learns to help others in the process of helping others. ${ }^{16}$

\section{Structure and Operation of Support Group}

Initiative support groups are classified into three groups ${ }^{16}$; - Online,

- Guided by professional leaders such as nurses, psychologists, social workers, 
- Peer leaders (self help). The most important element that provides support to the support groups is the leader.

It is important that the group leader is sensitive, flexible, and natural, so that the members can correctly identify their features and needs. The leader should ensure group harmony, provide accurate and consistent information, be effective in establishing sincerity as well as natural and open communication among group members. The leader takes part as a facilitator in the group. It sets the objectives of the group by evaluating the needs of the group members. ${ }^{13}$ When creating support groups, it is recommended to pay attention to the fact that the number of participating members is at least three and at most fifteen. ${ }^{16}$ It is important that the number of sessions, duration of the group, how many weeks the group will last, the number of members to be determined in advance and the status of the group members in determining these. ${ }^{13}$ In the studies, it is seen that the group sessions are done every week, biweekly and monthly. ${ }^{19,20,21}$ Group sessions can be performed during the diagnosis, treatment, recovery or palliative care.$^{13}$ More than one person cannot speak at the same time within the group. For this reason, the group leader should remind the members that they must first listen to each other and promise to everyone. The group leader should pay attention to the fact that group meetings lasting more than two hours create a vicious cycle, are repetitive and ineffective, and the meetings are within an average 80-90 minutes period for an effective support group initiative. ${ }^{16}$

\section{International Online Support Groups for Stoma Individuals}

There are many online support group organizations in the world for people with stoma. The Australian Council of Stoma Association, the Federation of Nz Ostomy Societies, the United Ostomy Associations of America, the Ostomy Canada Society, and the Colostomy Association (Figure 1). These organizations allow individuals with stomata in the same situation to talk to each other, share their experiences and feelings, and guide each other through the Internet.

\section{Support Group Intervention for Stoma Individuals in Turkey and in the World}

It organizes many different support group meetings with individuals with stoma in many parts of the world. For example; stoma support group meetings are held every month at Northwest Community Hospital. In group meetings, speakers, company presentations, group support and stoma nurses provide answers to the questions of individuals. ${ }^{22}$ In support group meetings at Aga Khan University in Nairobi, individuals discuss issues such as group rules, information and acceptability. They distribute the stoma materials they pack together before the meeting. Some of the group members who have been trained and

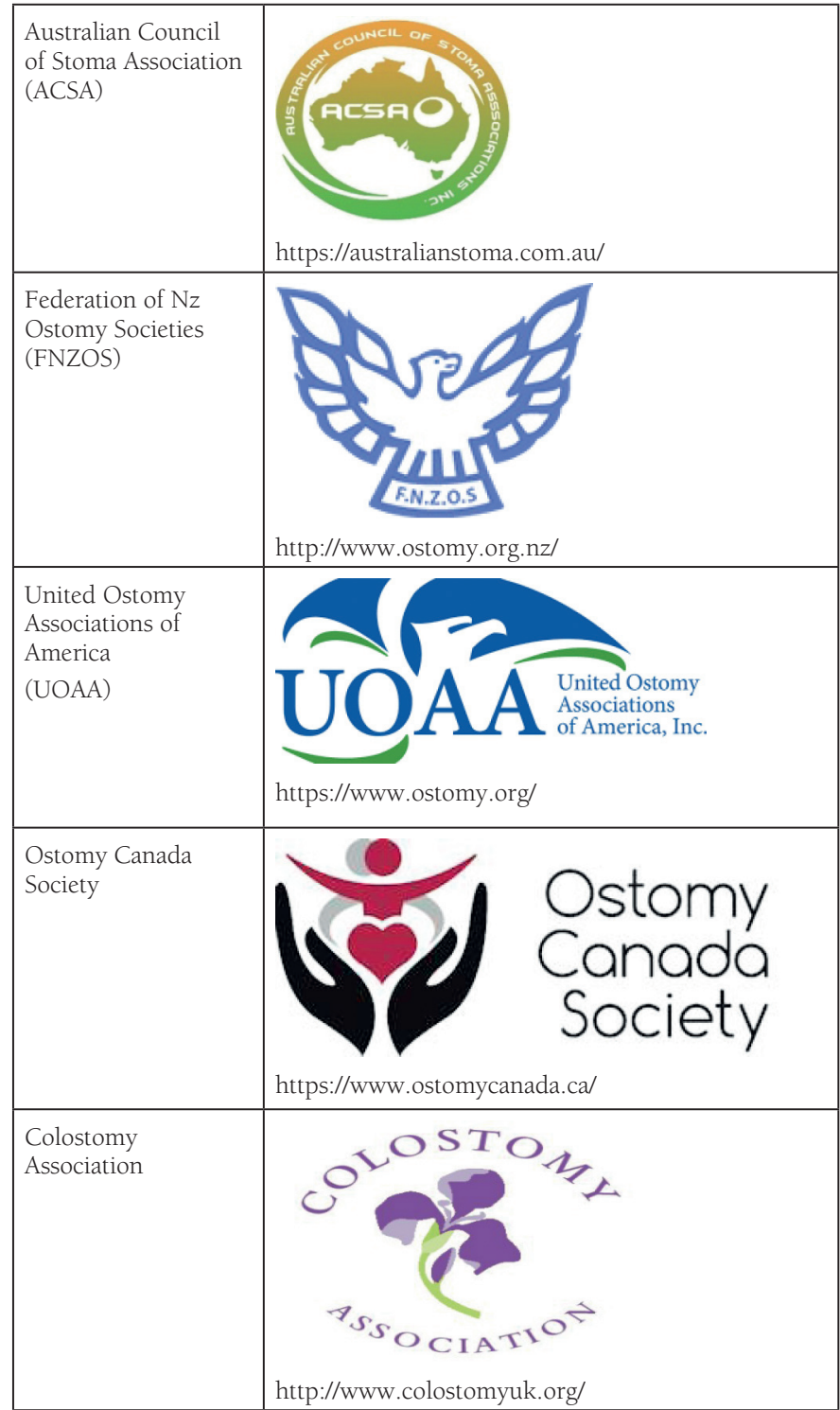

Figure 1. International online support group organizations

gained skills in a program help home users by opening a new stoma. ${ }^{23}$ Social meetings are held every two weeks in the form of morning coffee with the stoma support group called "inside out" at St Marks Hospital. Individuals attending the meeting meet with individuals with similar problems, share suggestions and have fun time..$^{24}$ In our country, since 2000, patients who have opened stoma have been given care, training and consultancy services in nursing units by trained nurses. However, there are no support groups in our country where stoma individuals continue. In the literature, no support group work for stoma individuals could be reached. In a study conducted with individuals with stoma in our country, weekly meetings were organized using planned group interaction. The meetings continued for six weeks and each meeting lasted 90 minutes on average. 
In the meetings, methods such as presentation by using computer and projection, using stoma care materials, group discussion around the round table, letter writing about the participants' stoma and reading the letters in group session were used. As a result of the study, it has been reported that planned group interaction increases the social cohesion of individuals with stoma. ${ }^{14}$

In the literature, there are other studies in which support group intervention is applied in other patient groups. As a result of a study in which support group intervention was applied to individuals with CRC, support group intervention was reported to increase the quality of life of individuals. ${ }^{25}$ In a study conducted with liver transplantation individuals, support group meetings were organized monthly and meetings were held on average for 90 minutes and a total of six meetings were held. In the meetings, information about the meeting subject was shared with the booklet prepared in advance. As a result of the research, it is reported that support group initiative is effective in increasing the level of knowledge of individuals and decreasing the symptoms of individuals, supporting the adaptation of individuals and improving the quality of life. ${ }^{19}$ In a randomized controlled trial, women with early stage breast cancer were divided into three groups. One hundred twenty-five women were given support group and training initiative based on Roy Adaptation Model. In the experimental group, 34 women received support group training in three stages and phone call for 13 months. In the first control group, 48 women received social support and training in three steps. In the second control group, 43 women received training only once by mail. As a result of the study, the experimental group and the first control group reported that they experienced less discomfort, less loneliness, and higher quality relationships than the second control group. ${ }^{21}$

\section{Result}

In order to cope with the psychosocial problems experienced by individuals with stoma and to ensure the social cohesion of individuals, stoma care nurses have important responsibilities. The responsibilities of the nurses include; to provide psychosocial support to the patients as well as their physical and to increase their adaptation to the disease. The nursing roles of the stoma individual for social cohesion are; to provide individual training and consultancy services, to support the individual to realize and use his/her own social support factors in his/her environment and to strengthen the support by meeting with his/her family and his/her relatives. In this regard, it is important to create support groups by bringing together individuals with stoma with other people with stoma. In our country, there is no continuous stomaterapy program or support group initiative. For this reason, it is recommended to plan, implement and increase the support group meetings where stoma individuals can share their problems in order to ensure social cohesion, ask questions, get information and benefit from each other's experiences.

\section{Ethics}

Peer-review: Internally peer-reviewed.

\section{Authoring Contributions}

Concept: S.S., F.V., Design: S.S., F.V., Data Collection or Processing: S.S., F.V., Analysis or Interpretation: S.S., F.V., Literature Search: S.S., F.V., Written by: S.S., F.V.

Conflict of Interest: There is no conflict of interest in this article.

Financial Support: No financial support was received from any institution or person for our study.

\section{References}

1. TC. Sağlık Bakanlığı Türk Halk Sağlı̆̆ı Kurumu Türkiye Kanser İstatistikleri 2017; Erişim tarihi: 30.06.2018 https://hsgm.saglik.gov.tr/depo/birimler/ kanser-db/istatistik/2014-RAPOR._uzuuun.pdf

2. Karaveli S, Özbayır T, Kahraman A. Stomalı Hastaların Sızıntı İle Baş Etme Yöntemlerinin İncelenmesi. Ege Üniversitesi Hemşirelik Fakültesi Dergisi 2014;30:18-25

3. Karadağ A, Korkut H. Peristomal Cilt Komplikasyonlarn: Öleme, Tedavi ve Bakım. Ulusal Cerrahi Dergisi 2010;26:175-179.

4. Ayaz S. Stomalı Bireylerde Hemşirenin Rolü. Türkiye Klinikleri J Med Sci 2007;27:86-90

5. Üstündağ H, Demir N, Zengin N, Gül A. Stomalı hastalarda beden imajı ve benlik saygısı. Türkiye Klinikleri J Med Sci 2007;27:522-527.

6. Yaşan A, Ünal S, Gedik E, Girgin S. Kalıcı ve Geçici Ostomi Yapılmış Kişilerde Yaşam Kalitesinde Değişim, Depresyon ve Anksiyete. Anadolu Psikiyatri Dergisi 2008;9:162-168.

7. Burch J. Ensuring Optimum Quality of Life in Community Patients with a Stoma. JCN 2014;28:21-26.

8. Pittman J, Kozell K, Gray M. Should Woc Nurses Measure Health-Related Quality of Life in Patients Undergoing Intestinal Ostomy Surgery?. J Wound Ostomy Continence Nurs 2009;36:254-265.

9. Kılıç E, Taycan O, Belli AK, Özmen M. Kalıcı Ostomi Ameliyatının Beden Algısı, Benlik Saygısı, Eş Uyumu ve Cinsel İşlevler Üzerine Etkisi. Türk Psikiyatri Dergisi 2007;18:302-310.

10. Vural F. Stomalı Hastalarda Yaşam Kalitesi. Cerrahi Bakım ve Yaşam Kalitesi Sempozyumu Konferans Konuşma Metinleri 2012;33-38.

11. Kimura CA, Kamada I, Guilhem D, Fortes RC. Perception of Sexual Activities and the Care Process in Ostomized Women. J Coloproctol 2013;33:145-150

12. Vonk-Klaassen SM, de Vocht HM, den Ouden ME, Eddes EH, Schuurmans MJ. Ostomy-Related Problems and their Impact on Quality of Life of Colorectal Cancer Ostomates: A Systematic Review. Qual Life Res 2016;25:125-133.

13. Tuncay T. Kanserle Başetmede Destek Grupları. Toplum ve Sosyal Hizmet 2010;21:59-71

14. Karabulut HK, Dinç L, Karadağ A. Effects of Planned Group Interactions on the Social Adaptation of Individuals with an Intestinal Stoma: A Quantitative Study. J Clin Nurs 2014;23:2800-2813. 
15. Leyk M, Ksiazek J, Habel A, Dobosz M, Kruk A, Terech S. The Influence of Social Support from the Family on Health Related-Quality of Life In Persons with a Colostomy. J WOCN 2014;41:581-588.

16. Yalom ID. (Çev.) Tangör A, Karaçam Ö. Grup Psikoterapisinin Önemi Teori ve Pratiği. Üçüncü Basım, İstanbul, Nobel Tip Kitabevi, 1992.

17. Aktaş MA. Grup Süreci ve Grup Dinamikleri. Ankara, Sistem Yayıncilık, 1997.

18. Mowdy S. The Role of the WOC Nurse in an Ostomy Support Group. J WOCN 1998;25:51-54.

19. Sarıöl Ordin Y, Karayurt Ö. Effects of a Support Group Intervention on Physical, Psychological, and Social Adaptation of Liver Transplant Recipients. Experimental and Clinical Transplantation 2016;3:329-337.

20. Erol Ursavaş F, Karayurt Ö. Experience With A Support Group Intervention Offered to Breast Cancer Women. Exp Clin Transplant 2017;13:54-62.
21. Samarel N, Tulman L, Fawcett J. Effects of Two Types of Social Support and Education on Adaptation to Early-Stage Breast Cancer. Res Nurs Health 25:459-470.

22. Support Groups and Therapy. Erişim Tarihi: 25.09.2018 http://www.nch. org/patients-visitors/support-groups-therapy/ostomy-service

23. Stoma World Kenya for the Highest Quality of Life of Ostomates. Erișim Tarihi: 12.12.2018 https://ostomyeurope.org/wp-content/ uploads/2017/01/Kenya_2013.pdf

24. Inside Out Stoma Support Group. Erişim Tarihi: 12.12.2018 http://www. stmarkshospital.nhs.uk/about/inside-out-stoma-support-group/

25. Carmack CL, Basen-Engquist K, Yuan Y, Greisinger A, Rodriguez-Bigas M, Wolff RA, Barker T, Baum G, Pennebaker JW. Feasibility of an ExpressiveDisclosure Group Intervention for Post-Treatment Colorectal Cancer Patients. Cancer 2011;117:4993-5002. 